\title{
The California Bungalow and the Tyrolean Chalet: The Ill-Fated Life of an American Vernacular
}

\section{Rodney Douglas Parker}

The California Bungalow is often considered the first truly indigenous form of American popular architecture. Because its success was so widespread, the California Bungalow is also viewed by many as a distinctive feature of American culture. Numerous authors ${ }^{1}$ have offered genealogies of this popular housing type, usually emphasizing its possible roots in Asia, particularly India and Japan. Yet there is good evidence that what eventually came to be called the "California" bungalow derived primarily from Swiss and Germanic sources. This might be of minor importance were it not for the fact that the California bungalow appeared on the American scene in the early 1900s, shortly before Britain and the United States were to enter the First World War with Germany.

When considering the role of architecture in a culture, one must take into account its special communicative potential. Architecture constitutes a powerful medium for conveying complex and ambivalent values: it concretizes them, makes them highly visible, and thus presents them as apparently stable and acceptable. As architectural historian Alan Gowans states, "historic architecture was a means, through visual metaphors, of establishing, proclaiming, and transmitting convictions-i.e., of making them held universally. Architecture both proclaimed and persuaded" (38-39). As such, architecture performed a rhetorical function: it persuaded people to adopt and adhere to beliefs and attitudes about which they may have felt uncertainty. As Gowans explains,

Architects created dramatic statements of mass conviction as much because people didn't hold them as because they did: their job was precisely to do this and so ensure orderly continuity of society and civilization. (99)

Gowans' observation essentially exemplifies what may be termed a socially formative theory of art: art not only passes along cultural values, it seeks to produce them. By contrast, the currently more familiar social reflection theories of art claim that artworks for the most part merely mirror the prevailing, universally held values of their temporal and cultural contexts. Gowans responds, however, that meaning in historic architecture "was never a reflection of convictions held throughout society" (38). Social values were never so powerfully uniform that they could spontaneously generate full-blown architectural styles. Nor could designers afford to be so completely passive that they merely passed on whatever attitudes happened to be "in the wind" at the time. Designers and their clients most certainly responded to already existing values. However, they also used architectural form to shape and secure values, values that might elsewise be disputed, obscured and submerged by other societal forces.

There is reason to believe that the California Bungalow was just such a form. As a highly popular style of domestic architecture, it did not just submissively display mass attitudes. More actively, bungalow design endeavored to further shape those attitudes and more firmly establish newer ones. But apparently because of the nature of the convictions it espoused, the California Bungalow, by the end of the Great War, had come into conflict with the ascendant conception of core American values.

As $\mathrm{H}$. Allen Brooks' observations suggest, the California Bungalow was one manifestation of a much wider cultural and artistic reform movement (344-345). Along with developments in California, this reform embraced the architecture of the Arts and Crafts Movement, the Prairie School, Art Nouveau and the Austrian Secession movement. The California Bungalow thus closely related to other contemporary domestic styles that borrowed from these national and international movements. In the literature of the time the words "artistic" or "progressive" were often used to refer to these styles. While the bungalow here serves as a starting 
point, the terms Bungalow-Craftsman house (or simply, Bungalow-Craftsman) and progressive house will be used more broadly to include consideration of the stylistic family centered around the Bungalow. This study, then, will examine some of the sources, themes and cultural associations of Bungalow-Craftsman design, particularly its links with Germanic culture. Out of this will emerge the implications these themes and associations had for the decline of bungalow design.

Bungalows and progressive houses of the San Francisco Bay Area-particularly the East Bay, embracing Oakland and Berkeley-formed the core of the present work. Study of architectural evidence visible in the Bay Area points to larger movements in the national culture of the early twentieth century. An important notion in this analysis is the concept of the rhetorical "place" or locus. In classical persuasion theory, a locus, or "place" may be regarded as a basic unit of appeal or an accepted element of conviction. Pursuing the inherent spatial metaphor, a rhetorical "place" may also be seen as a region of consensual overlap or agreement. Thus, the viewer or audience finds the "place" familiar and acceptable, easy to associate with, or contextually appropriate. In this aspect, the rhetorical "place" may appear as an emotionally familiar element of the culture-a cultural locus, so to speak. In American culture, the principles of "democracy" and "that all men are created equal" are just such loci. In architectural design, the locus or "place" can also be considered a familiar schema of visual organization-e.g., the "ranch house" or "Greek temple"-used as a starting point for shaping a new work of architecture. With this in mind, let us now take a look at the rhetorical place and cultural locus of the Bungalow-Craftsman house.

\section{Tyrolean Architecture in the Bay Area}

It was in the first decade of the century, simultaneous with the ascendancy of the California Progressive Movement, that the California Bungalow and Craftsman house emerged as the advanced fashion in popular domestic architecture. Eastern clients had remained much more conservative than the West Coast buyers who sought out these new, single-family homes. With their preference for the neo-Georgian or Colonial Revival house, Easterners seemed preoccupied with publicly asserting a British or Yankee mainstream pedigree or with reinforcing the image of a static social establishment. To this day, for example, instances of the California Bungalow in the BostonCambridge area are rare to non-existent while
Georgian and Colonial Revivals are fairly abundant.

Western preferences were clearly different, and certain conditions before the First World War may explain why. California home buyers, especially in the San Francisco Bay Area, largely comprised middle-class merchants, educated professionals, white-collar workers and skilled craftsmen-groups that had become quite disenchanted with the existing political and social status hierarchies. Thomas Gordon Smith and others have shown how Progressive middle-class businessmen and educated professionals were an important component of the East Bay Area real estate market. ${ }^{2}$ As a group, they espoused "Progress through Development" and were deeply concerned with improving the East Bay's physical image. They saw among their chief antagonists in this effort large, absentee corporate monopolies such as the Southern Pacific Railroad. In 1905 the Progressives took control of Oakland City Hall with the election of Frank K. Mott as mayor. Statewide, from 1900 to 1915 California Progressivism rose as a major force for social change, a development that was paralleled throughout the nation. The philosophy of John Dewey gained popularity with the progressive middle class; E.F. Goldman tells why:

Here was a philosophy and a psychology perfectly tailored to progressive needs.... This vogue can hardly be explained except in terms of the fact that a good many Americans were weary of ways of thinking which froze them in a society they did not like. (122-123)

Richard Hofstadter elaborates further on the alienation of the new, educated professionals and artisans, groups that had been created by America's rapid industrial growth. What Hofstadter finds interesting

is not the changed external conditions of American society, but the inward social and psychological position of the professionals themselves.... The alienation of the professionals was in fact a product of many developments, but among these the effects of the status revolution must be given important place. Conditions varied from profession to profession, but all groups with claims to learning and skills shared a common sense of humiliation and common grievances against the plutocracy. (149)

This disaffected middle class suffered acutely from what might be called a paradox of discontinuity and connectedness, a condition which attracted some to socialistic philosophies. Alienated from the status quo structure of power and prestige, they yet felt commonality with other disinherited and marginalized elements of society. Those immigrat- 
ing to California in search of better jobs and housing tended to prefer designs which gave concrete public expression to their condition, values and world view. An article in the 1914 Architect and Engineer of California indicates what they were not looking for:

Thus the so-called Colonial style is really a diluted Baronial.... The heavy porticos that make a Georgian manor house so imposing, when transplanted to a pioneer community and rendered in painted pine, while not devoid of a historic interest, must always seem a little prim, a little cold for comfort, for coziness we demand in a home. (88)

In contrast to the Colonial style house, the more preferred California Bungalow-Craftsman, especially in the Bay Area, strongly reflected a popular fascination with Swiss and Tyrolean vernacular architecture that developed at the end of the 19th century. Several publications were influential, among them, two books from Europe: the lavishly illustrated Charakteristische Holzbauten der Schweiz and Der Schweizer Holzstil of 1877 by Ernst Gladbach (Figure 1). Architectural Record offered "The Wooden Houses of Switzerland" in 1897. William Dana's Swiss Chalet Book collected together a series of articles begun in the periodical Architecture and Building in 1911. In the first dozen years of the century many similar publications appeared with applications to American housing, often illustrated by the executed designs of architect Bernard Maybeck.

As a part of this trend, in the same 1912 volume with a piece by Frank E. Wallis on the Georgian colonial, Louis J. Stellman contributed an article on Swiss chalet design in America. For the middleclass residents of the picturesque hills of Berkeley and Oakland, the Swiss chalet seems to have presented a ready-to-hand schema, the architectural locus of choice. Notes Stellman, "Probably there is no place outside of its native land where the Swiss chalet may be more advantageously used than along the Pacific coast hills, particularly those around San Francisco Bay, where many interesting examples are to be found" (39). For Stellman and others, these steeply wooded hills seem to have evoked the natural picture of the Alpine mountaineer.

His love of the out-door life produced the broad veranda (forerunner, undoubtedly, of the modern winter-and-summer sleeping porch), the wide eaves to protect this veranda and the court below, where he sat of an evening with his pipe. He courted the open at all times possible, this old Tyrolese, and the Californian is in agreement with him....(39)
In this image we can observe at least two things of interest. First, there is definite reference to some of the characteristic architectural features of the California bungalow, namely, living verandas and the distinctive wide eaves that cover them. (In German, these were called die Lauben, a term denoting the chalet's verandas and loggias, but also denoting the entire summer-house as well.) Second, we can observe a developing paradigm in which the Swiss mountaineer serves as a symbolic model of the new open-minded, progressive middle-class. This openness was also thematized architecturally by the visually open form of the chalet and the bungalow. A key factor in the attraction of Swiss vernacular design was the deep spatial interlock the wide eaves, verandas and balconies typically formed with the natural surroundings. The image evoked of shady bowers and cozy summer cottages seemed tailor-made for the Berkeley hillsides.

In addition to the appropriateness of overall form, Swiss holzbau construction naturally recommended itself to the then abundant redwood resources of Northern California. Even the more economical stucco construction (Figure 2) had a model in the use of concrete, roughcast and masonry in contemporary chalets in Canton Graubuenden, Switzerland, one of which is illustrated in Stellman's article. Indeed, houses in the nearby Engadine valley of Graubuenden typically exhibit stone and stucco construction, these along with their Austrian kin having recently been designated collectively as the "piedmont folk-house group" of Tyrol (Figure 3) (Suzuki 67). (Following Stellman's usage, Tyrol here is broadly meant as the geographical region embracing the Austrian provinces of Tyrol and Vorarlberg, the southern portion of the German state of Bavaria, the Italian departments of Trentino-Alto Adige and northern Lombardy, and the Swiss canton of Graubuenden. As a convenience I refer to the architectural style simply as Swiss-German or Tyrolean.)

In all of this the notion of the locus is paramount, not only in that it applies to the SwissGerman folk-house as a readily available, appealingly recognizable architectural schema. The locus is also important here in its physical/spatial sense, that is, in the way it points out the appropriate matching of built-form with a local geographic condition.

Apparently, much of Swiss styling was introduced to the Bay Area through exact replication. Says Stellman: 


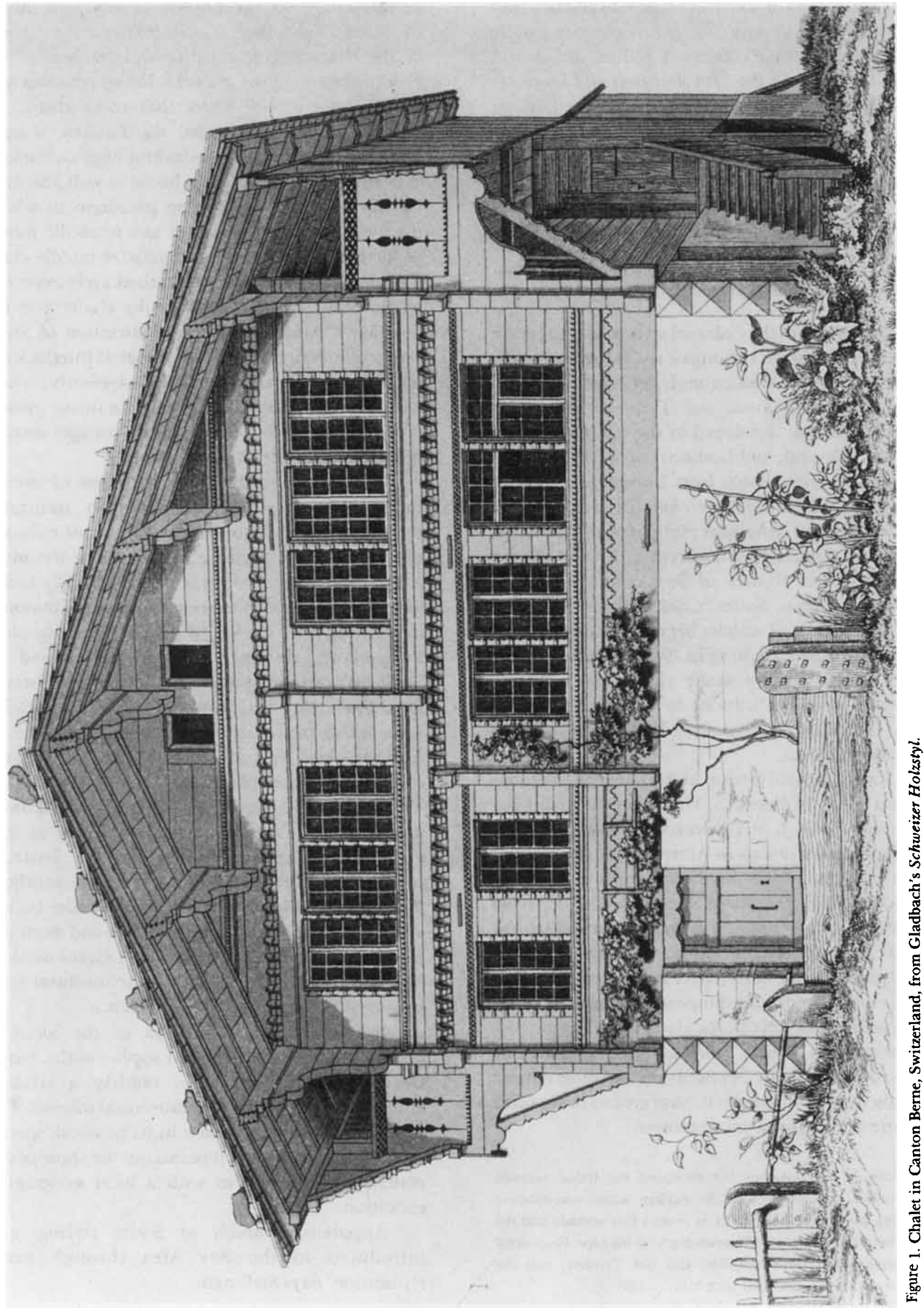




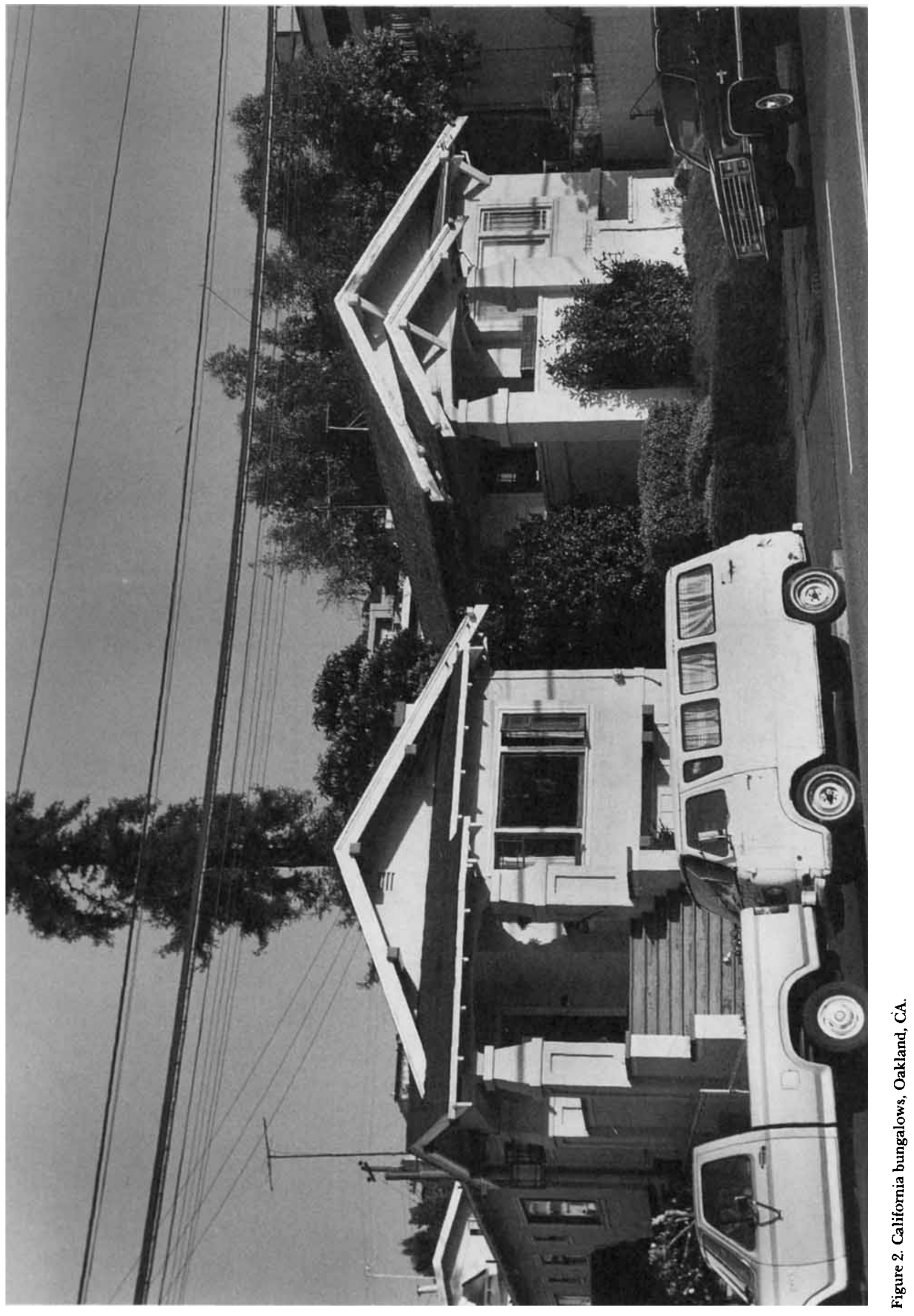




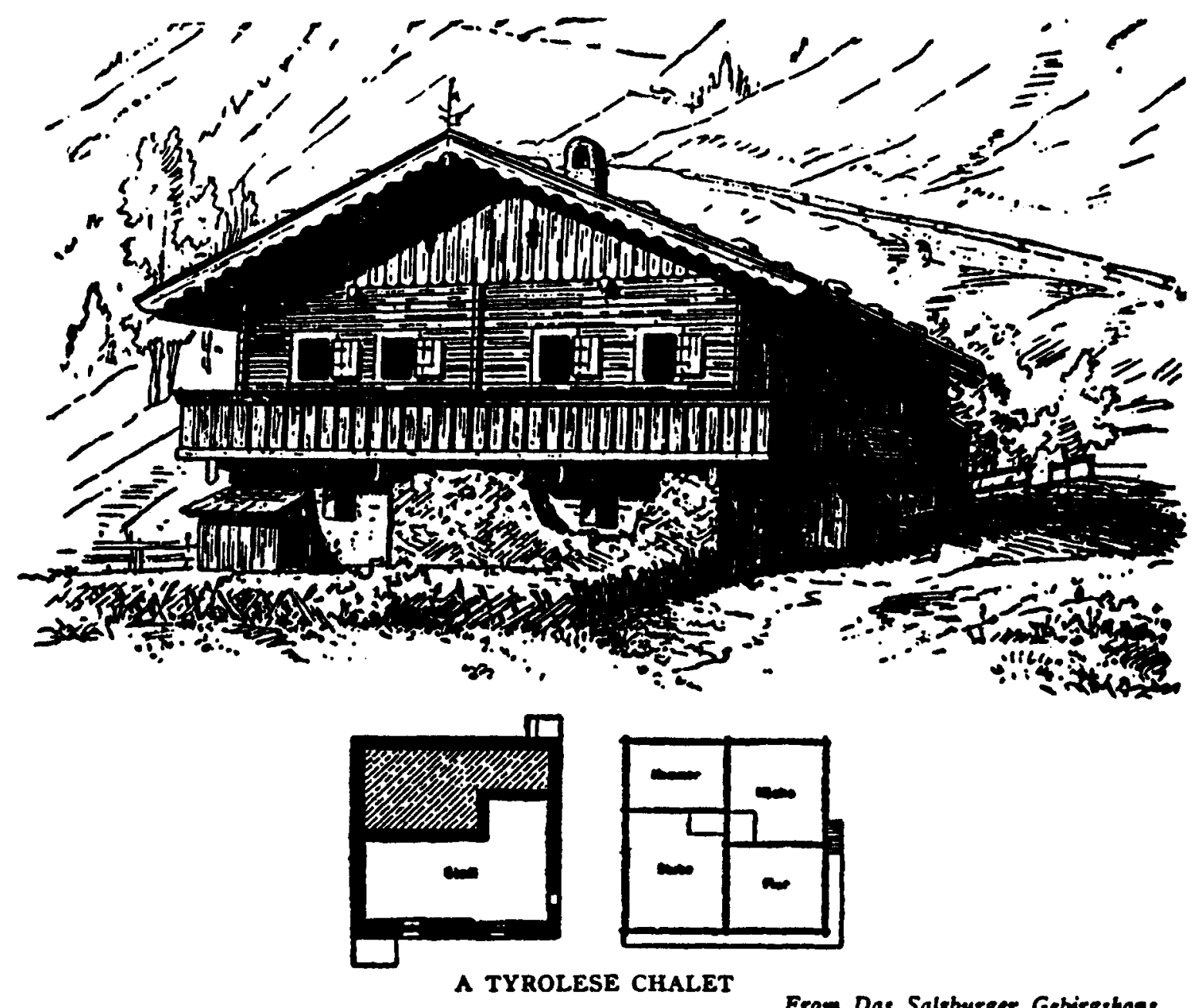

Figure 3. "Tyrolese" Chalet from Dana's Swiss Chalet Book. 
A number of Western houses are exact copies of existing Swiss chalets, notably the Reese house in Berkeley, California, which was designed by Maybeck \& White from a small model of the Swiss prototype which Reese himself brought across the ocean. (42)

The popularity of this tightly-copied style is now perhaps rather difficult to imagine since many of these chalet-type designs were destroyed in the catastrophic Berkeley fire of 1923. Stellman's remarks indicate they were indeed quite numerous.

Alameda county, which includes Berkeley, Alameda, Piedmont and Oakland, and which abounds in hills, furnishes many fine examples of Swiss chalet architecture and a much larger number of less distinctive ones which are, nevertheless, of more than passing interest and display quite perceptibly their relationship to the architecture of the Tyrol. (43)

These picturesque residences no doubt inspired even greater numbers of less expensive developerbuilt imitations in the flatlands. With these, the Bay Area bungalow and its kin in all probability trace architectural lineage back to those hilldwelling Swiss-German chalets. In 1911 Henry Saylor virtually declared the American chalet as a variety of bungalow:

Another distinct type of the bungalow is an adaptation of the Swiss chalet. Most frequently is it to be found on the mountainsides and foothills of the West.... The characteristics are, perhaps, too well known to need mention-the extremely wide overhang of the flat-pitched, two-planed roof, the frequent presence of a balcony in the gable ends, and the use of sawedout openings between adjacent boards as a means of decoration. The chalet as found in Switzerland is by no means confined to one floor, so that it is not surprising to find the American development of this building making more of the attic than the true [Bengali] bungalow type. (29-30)

Designers and builders seem to have generally accepted this designation. In fact, the terms "chalet bungalow" and "Swiss chalet style" were used by bungalow designers well before the publication of Saylor's book. Architectural Record illustrated a 1 1/2-story "Bungalow in Swiss Chalet Style" in a 1905 article (223). H.L. Wilson's Bungalow Book of 1908 shows three explicitly designated "Swiss chalet" designs and at least four others with conspicuous Swiss styling. ${ }^{3}$ By 1913, the Bungalowcraft Company (Henry Menken) of Los Angeles was illustrating a number of one- and two-story "chalet bungalows" in its annual catalog. The term "lowpitched" or "flat-roofed" was usually applied to single-story chalet bungalows while 2-story models were described as having "chalet lines." It is significant that the "flat-roofed" chalets shown essentially correspond to our now-standard conception of the "California" Bungalow. Indeed, we can see the models of "pure" and "California" bungalows in these and later plan books as basically built around the typical "low-pitched chalet" design (Figures 4, 5; compare Figure 6). ${ }^{5}$

As for the deeper social and cultural appeal of the Swiss chalet bungalow type, the title-page blurb from a bungalow catalog of Los Angeles' De Luxe Building Company crisply expresses the motivation of its targeted market:

More homes by the De Luxe Building Company for progressive people who wish to build homes that are different. Introducing our latest and newest modified Swiss chalet and Japanesque architecture...

In sum, this little bit of audience identification implicates an underlying proselytical intent: namely, that the chalet bungalow aimed to publicize architecturally the existence of an alternative, nonmainstream Weltanschauug. The Swiss-Tyrolean bungalow served-or was attempting to serve-as visible testimony to an emergent, populist, countercultural attitude.

\section{Other Design Influences}

Especially when one considers the contrasting mania for Anglo-Saxon colonial symbolism elsewhere, the Bay Area popularity of modified Swiss-German elements in Bungalow-Craftsman and progressive house design is only partly explained by the success of the Berkeley hillside chalets or the philosophies of new progressives. Additional components of this popularity may be found when we look at people who shaped the bungalow form: its designers and architects and particularly, German-Americans who influenced Bungalow-Craftsman architecture.

In discussions of Bay Area architects influencing the bungalow, one name occurs repeatedly: Bernard Maybeck. A highly creative artist, Maybeck was a second-generation German-American, the son of a German woodcarver. Before the great Berkeley fire he executed numerous residences exhibiting Swiss and German medieval elements, and the Berkeley "Brown Shingle" house and the Bay Area Craftsman bungalow clearly derive from his work. Another early figure influencing the course of Bay Region design was A.C. Schweinfurth, the architect of the Unitarian Church on Bancroft Way in Berkeley. Schweinfurth, another second-generation German-American, qlso was the son of a German woodworker. A third architect, Louis Christian Mullgardt, also established himself before the War and, like Maybeck, strongly shaped Bay Area 


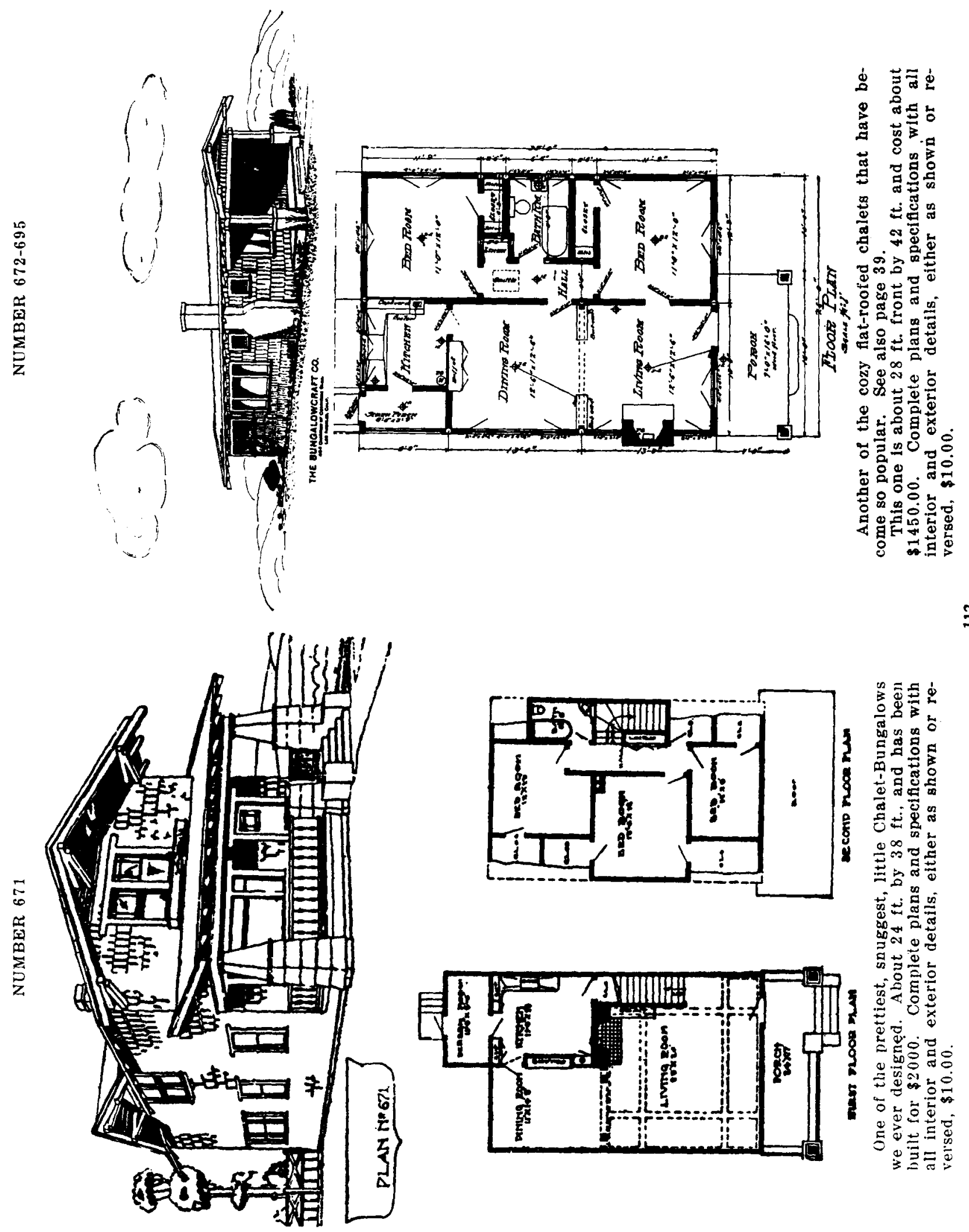



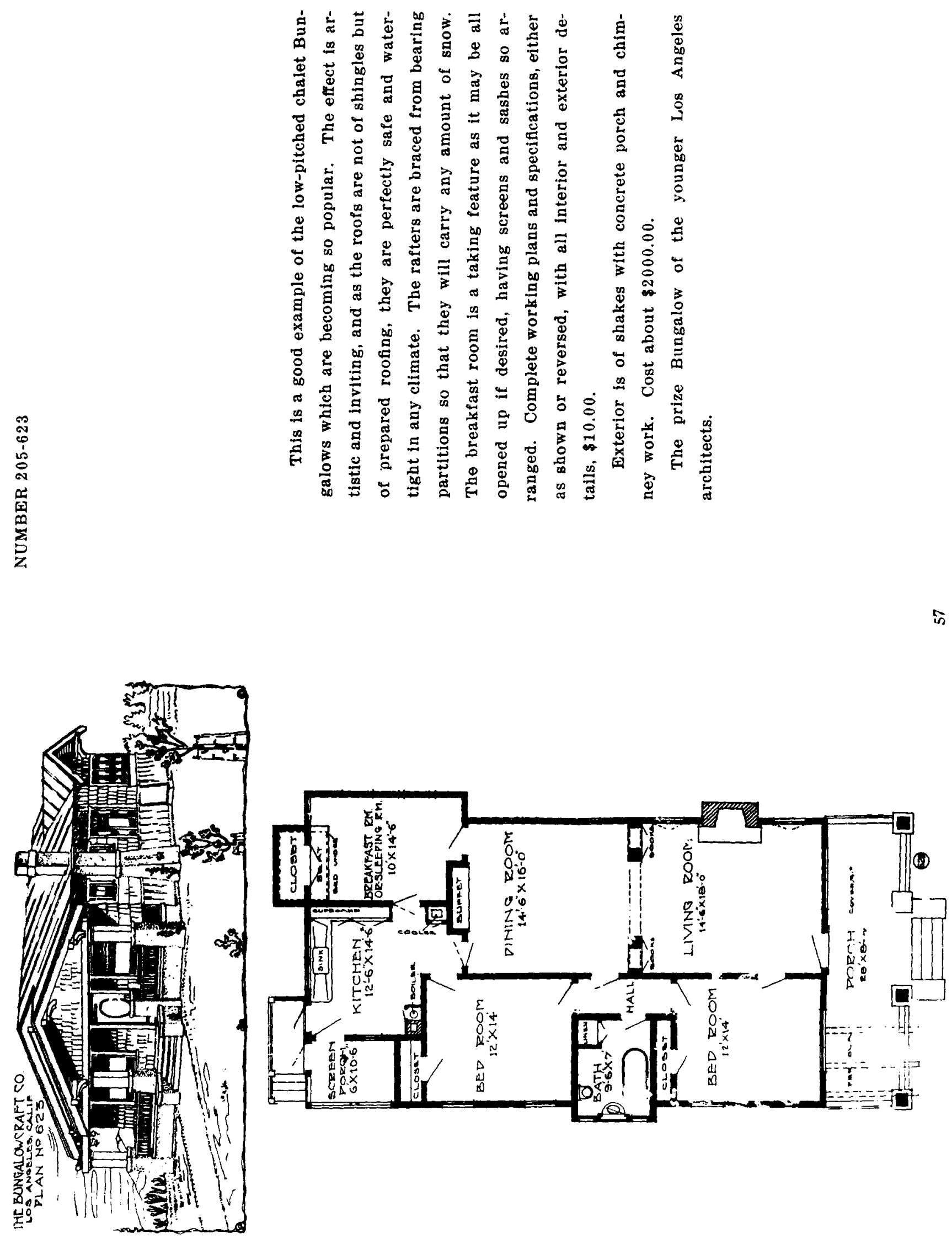


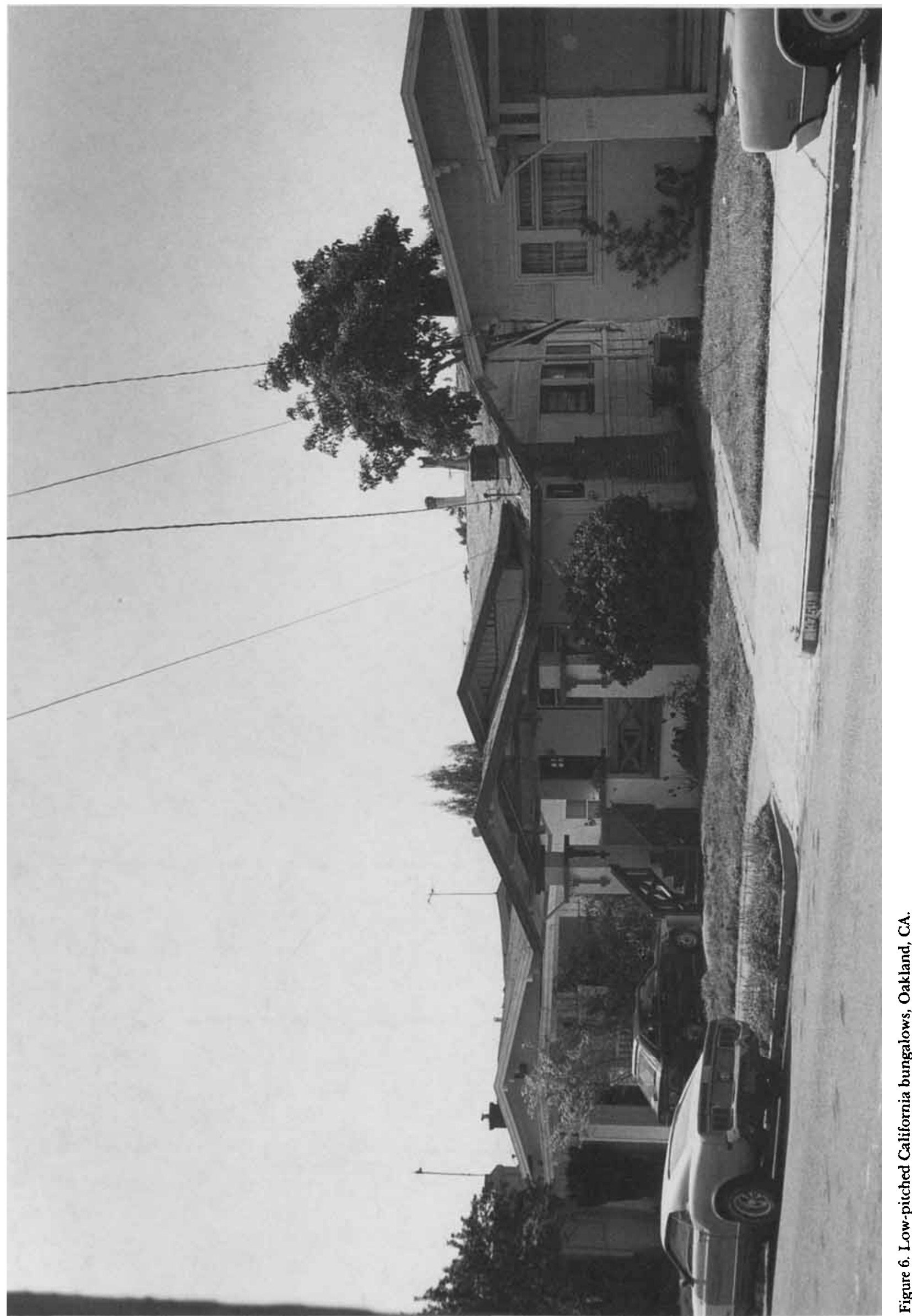


residential design. Born in 1866 in Missouri, Mullgardt, too, was second-generation GermanAmerican, his parents having immigrated from Prussia and Schleswig-Holstein (Clark 252, 254). The influence of his work done in Marin, Berkeley and Piedmont can be seen in the designs of bungalows and progressive houses throughout the East Bay. Mullgardt's executed buildings used Germanic configurations and motifs, but unfortunately few remain standing today.

At the national level, an important figure in the bungalow's development was certainly Gustav Stickley, the head of the Craftsman Movement. Stickley was German-American and spoke German as his first language. Born in 1857 in Wisconsin, he was the eldest son of Leopold and Barbara Brandt Schlager, who later changed their last name to Stickley. Publishing bungalow designs regularly in his Craftsman magazine, Stickley freely adopted Swiss and Tyrolean forms to improve the image of his stucco clad houses. Robert Winter observes that "Craftsman" denotes several styles including the "Swiss Chalet and Bavarian Hunting Lodge" (12). An examination of the publication More Craftsman Homes, indeed, reveals a substantial number of Alpine architectural references. For Stickley $\log$ building was also a familiar technique, as German Blockbau construction was widely practiced by the German settlers of Wisconsin. Many of their Blockbau farmhouses were of the "saltbox" configuration, having a single gable roof with one side extended downward to incorporate a rear leanto shed. Significantly, many of Stickley's Craftsman farmhouse designs exhibit this same saltbox profile.

The Pasadena architects Charles and Henry Greene are sometimes credited with inventing the California Bungalow. Though not of German ancestry, the Greene brothers were born in predominantly German Cincinnati, Ohio. Moreover, they spent their adolescence in St. Louis, Missouri, one of the nine leading "German" cities in 1900 (McCoy 103-104; Hawgood 81, 85). Many of their earlier small houses were noticeably SwissTyrolean inspired, exhibiting the characteristic low-pitched roof, wide eaves, exposed purlins and rafters and shingle cladding. Several of these were illustrated in Architectural Record in 1905, including the Libby Residence, a project conspicuously derived from Swiss chalet design (Figure 7) (306-315). Karen Current confirms the key role of the Swiss chalet in the Greene brothers' residential style, noting that it was the mentor of their unique architectural synthesis. ${ }^{6}$
Other designers influencing the bungalow style-notably, Frank Lloyd Wright-were from western or Midwestern states lacking a deeply entrenched old Anglo-Saxon elite, but often having a quite visible German presence. Maybeck, Mullgardt and Stickley were all certainly GermanAmericans, a group-as William Rhoads has noted-distinctly absent from the heart of the colonial revival movement. ${ }^{7}$ Though Stickley sometimes mildly colonialized his designs, with his reference to "our Germanic ancestors" in some of his publications he clearly placed himself outside the spirit of the neo-Georgian renaissance. It seems fair to assume that likewise did many of his clients and buyers.

\section{Further Themes and Associations}

Of the several overlapping themes that relate the visual form of the bungalow to the convictions and values of its audience, at least three deserve added emphasis here. Each theme has an analogue in a definite compositional tactic employed in bungalow design.

1. Collectivity and collective action. To overcome the intransigence of the established syndicates, Progressives looked to build wider political affiliations through a permeable, ever-expanding and inclusive middle class. In Oakland, California, civic reformers had to counter the paralyzing factionalism of individual interest groups and political machines. They did so by championing the broader collective goals of the city with the rallying cry, "All Together for Oakland!" (Enquirer, May 54-56). In general, progressives tended to work for the civic collectivity and against narrow-interest political cliques. Many of these more collective and socialistic policies-e.g., zoning, government welfare, workmen's compensation-were borrowed or imported from Germany, presumably by American travelers and new immigrants.

The idea "All Together for Oakland" acquired a fitting architectural reinforcement in the streetscapes of Oakland's new bungalow neighborhoods. Chunky surfaces and chopped-up vertical planes typically modulated the BungalowCraftsman's exterior envelope. Chiefly responsible for this effect were the emphasized masonry elements-pedestals, chimneys, porch piers, copings and foundations-along with the many projecting bays, oriels, dormers, purlins, eaves and lintels. The overall bumpiness of the outer envelope de-emphasized the actual weather-tight closure and self-containment of the individual house. At the street scale, seen obliquely from pedestrian's-eye 


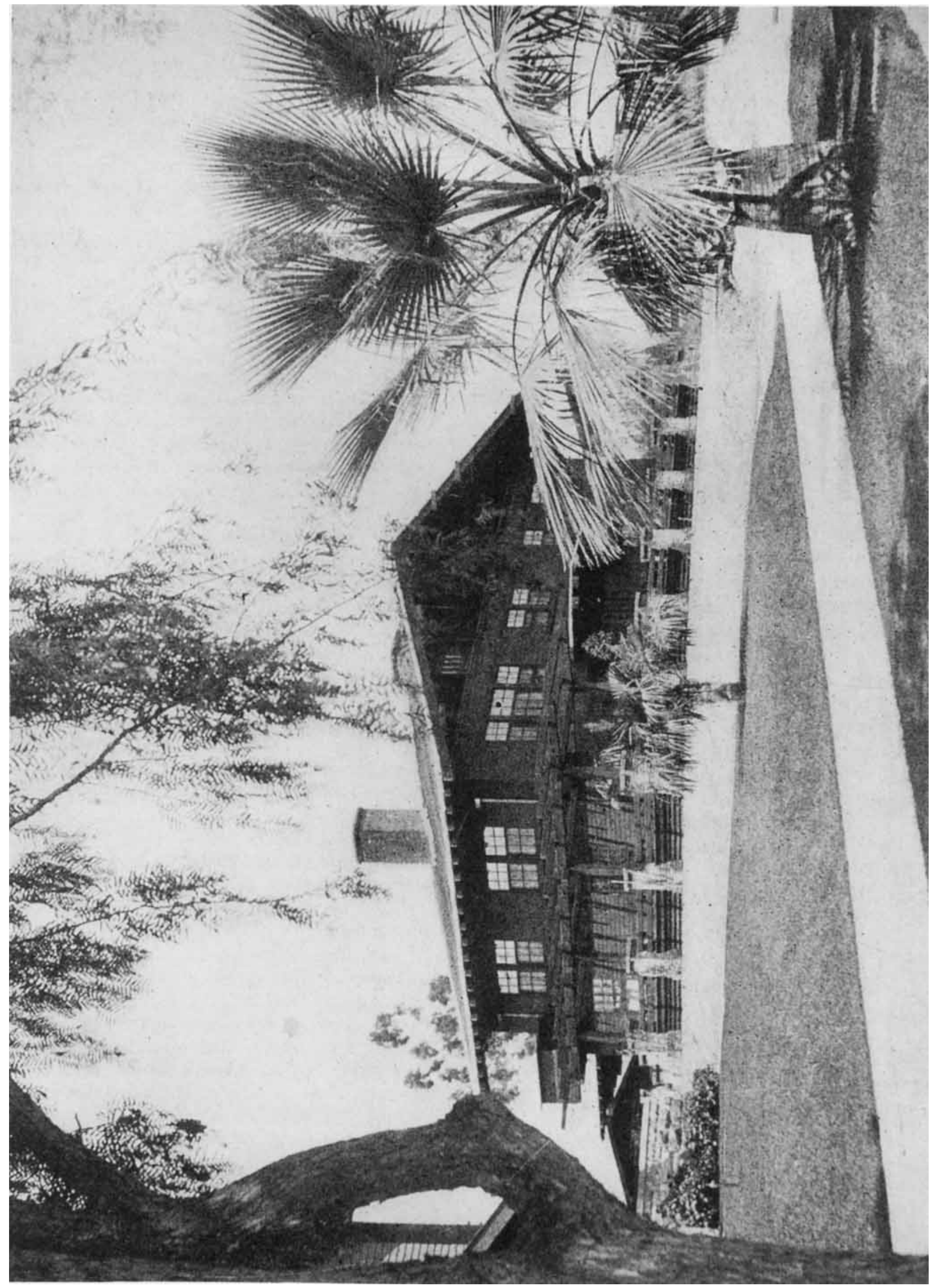


view, this de-emphasis allowed several adjacent bungalows to compose together visually. The image of atomistic, self-centered dwelling units thus dissolved into a cohesive assembly of gables,chimneys, porch columns and stair parapets. The resulting larger-scale impression formed the important architectural metaphor: a block-scale dwelling manifesting a new model of collective civic connectedness.

2. Openness. As already mentioned, progressives valued a certain open-mindedness that looked beyond the old social barriers and political systems of the established plutocracy. In a metaphorical and physical sense, that openness found expression in a new interest in nature and the out-of-doors, but more direct social openness also gained affirmation. As Robert Wiebe observes, many good-willed progressives professed faith in the "gentle assimilation" of the American newcomer. Likewise, reformers embraced a "belief in the mystical Americanizing powers of the soil" (Wiebe 209-210).

Architecturally, bungalow designers conveyed this openness by emphasizing the inter-penetration and interlocking of outside and inside spaces. Fundamental in effecting this open interaction were the in-between elements of the house: generous verandas, patios, pergolas, projecting bay windows and dormers. Ample picture windows that revealed cozy living-room interiors often added to the expressed openness of the progressive house. Openplanning characterized bungalow interiors, too, distinguishing them from the more cellular arrangement of rooms found in Colonial Revival houses.

3. Movement. The Bungalow-Craftsman's California clientele (or California-bound clientele) was unlikely to have been rooted in the same locale for a long time. Indeed, California's development depended on attracting immigrants: people moving from Europe, the eastern and Midwestern U.S., even from one California city to another. Not overlooked by designers was the fact that the newcomer's orientation to movement comprised a sociopolitical as well as a geographical component. Many of these newly-trained professionals and tradesmen found that their acquired skills allowed access to preserves formerly restricted to high social classes. This upward mobility-and its attendant frustrations-was reflected in many of the tenets of progressivism and its social reform programs.

To convey visually this now-essential appearance of dynamism and mobility, BungalowCraftsman designs emphasized horizontality. Serving this end quite well was the original SwissTyrolean chalet model with its low, broad roof eaves and long ridge line. Additionally, the long, low chalet roof evoked the equally important feeling of "repose"-a word used often in bungalow literature. Without appearing static, chalet horizontality helped communicate that everimportant image of California relaxation, a vital ingredient in the state's sales appeal. That these effects can be tellingly conveyed by such a horizontally stressed building has been observed by Rudolf Arnheim:

Easy mobility in the horizontal plane becomes the dominant characteristic of the entire building... [T] The building conforms to what Frank Lloyd Wright called the earth line of human life (the line of repose)'.... The horizontal style of living promotes interaction, free mobility from place to place, and ease of progress, whereas vertically oriented living stresses hierarchy, isolation, ambition, and competition. (38-39)

The British-derived Queen Anne and Gothic Victorian designs had thus urged a mobility that came to seem pushy, frenetic, too excited. The California Bungalow-Craftsman, by contrast, promoted a convivial, easy-going, leisurely pace. Westward travel thus promised sanctuary to more and more Americans. It was a way to find respite and peace-of-mind, and with the bungalow, a means by which modern life's tensions were to be avoided rather than amplified.

The Decline of the Progressive House

Before the onset of the War, in addition to Midwestern victories in Milwaukee and Minneapolis, American socialists gained control of the city government of Berkeley, California. As this latter victory indicates, socialist philosophies were wellaccepted in the East Bay. Nationwide, however, socialism entered into a perceived triple association, an unfortunate association that perhaps helped undermine the acceptance of bungalow and nonmainstream, progressivist imagery in architecture. Socialists were often viewed as the left-wing offshoot of the progressives, but socialism soon became linked with Germany, the country of its origin. The Wisconsin-based German Socialists, by 1912, were the dominant force in the American socialist party (Wiebe 207). By 1915, due to the War, German culture was being connected with anti-English activity, and by 1917 , with anti-Americanism. ${ }^{8}$ Until 1917 many German-Americans had openly advocated American neutrality in the war, while other Germanic groups staunchly embraced pacifism by religious conviction. These and similar neutralist sentiments had heightened country-wide fears of alien sedition, thus fueling antiradical activity. Some U.S. Congressmen with large 
constituencies of German-Americans had opposed American entry into the war. Some of these same politicians had also advocated certain socialistic programs that as a consequence became associated with alleged pro-German influence. ${ }^{9}$ These conditions had been complicated even further by a 1915 recession, a factor in itself antagonistic to liberal reform efforts; this recession was alleviated only by a dependence on income from war shipments to the European Allies. Through the socialist and neutralist associations, overt Germanism aroused fears of militant revolutionary activity. The Russian revolution and the Irish Republican rebellion hardly ameliorated this perception; indeed, in 1917 Americans came to believe that Germany was behind the Bolshevik uprising. Even before this, critics of national reform had started labeling progressivist efforts as "socialism" and "communism" (Wiebe 289, 209). Hence the fatal triple association: Progressivism, Socialism, Germanism. Progressive ideology in this way became tainted with suspicions of political subversion.

Another more architectural association may have also developed: the progressive house may have been thought a manifestation of the Viennese Secession artistic movement. Thomas Gordon Smith conjectures that this Germanic link may have forced Berkeley architect John Hudson Thomas to abandon the assertively liberal residential style he developed before the War (56). Frank Lloyd Wright and the Prairie School were seen by some writers as the American branch of the Austrian movement. ${ }^{10}$ Similarly, all reflections of Arts and Crafts or Craftsman Movement design perhaps became viewed by many as outcroppings of Austrian avantgarde architecture; Stickley's known German background probably strengthened this presumption.

It is not clear how much the general public really knew of the Viennese Secessionists and their German colleagues. In any case, the practices of no liberal, progressive designers survived the First World War without radical changes. The Prairie Style succumbed apparently at the very outbreak of war in 1914. Stickley's business ventures were finished by 1920 . The practices of Mullgardt, Maybeck and the Greene brothers suffered irreversible declines during this period. John Hudson Thomas adjusted by shifting to an overtly Tudor or English vernacular after the War. Others reverted to markedly classicized or Mediterranean designs. Frank Lloyd Wright did emerge as the most successful survivor, but precisely during the War he adopted unmistakable Meso-American forms and motifs that radically changed his designs.

By any estimate then, the pressures of international politics exerted a measurable influence on the perception and conception of American culture during the century's second decade. Specifically, running alongside disloyalty worries, a parallel social current pushed increasingly for unbending Americanization. Fears of unmanageable workers intensified demands that "hyphenated" Americans abandon all foreign ways (Wiebe 288). This in turn engendered a heightened cultural nationalism among the "hyphens"-a wish to be "different"1 —as a reaction to coercive Americanization. But increased expressions of ethnic distinction convinced even more people of the lack of national cohesion, and that the country was in constant danger of alien treachery. The supposed need for preparedness thus rationalized even harsher Americanization pressures (Wiebe 288). Once America entered the war in 1917, this anxiety over cultural disunity culminated in a purge that essentially expunged many signs of Germanism from American culture. In some cities such as Los Angeles, German books were burned and the teaching of the German language was banned. Some German-language newspapers were suppressed, while others, like San Francisco's California StaatsZeitung, could publish in German only if a "true" English translation was filed with the U.S. Government. In some cases German-Americans were forbidden to speak their native tongue in public. In Oakland and elsewhere, those who did so risked being turned in as alien subversives and were often physically assaulted. Karl Munch, the conductor of the Boston Symphony Orchestra, was imprisoned as an espionage suspect. Beethoven, Bach and other German composers were dropped from concert programs. As a consequence of this massive cultural purge, many Americans of German, Austrian and Swiss descent changed their surnames and otherwise disguised and denied their German ethnicity. Street names, place names and even food names were also changed. ${ }^{12}$ Perhaps not until the late $30 \mathrm{~s}$, with the arrival of Walter Gropius, could Germans make an openly public contribution to American architecture, and then quite significantly, only as the champions of the "International Style".

The Great War had shown the issue of ethosthe process of persuading one's fellows of one's personal character and affiliations-unavoidably implicated in the choice of architectural style. Illustrating the point is the case of Cardinal Mundelein of Illinois, an archbishop of German 
descent, who felt compelled to commission a colonial revival church to demonstrate his own patriotism and that of his mostly immigrant parishioners (Rhoads 350-351). Similarly, for the sake of establishing loyalty to country, most architectural clients had to avoid any visible hint of German sympathy or counter-cultural attitudes. To meet this need, house designs metaphorically embodied universal conformity: emphatically regularized massing, tight volumes, undivided planar surfaces, and unbroken lines of visual composition became the norm. The features of American domestic architecture began to show that they could "toe the line." And indeed, such were the key design characteristics exhibited by the neoGeorgian and Colonial Revival house.

Thus the vigorously progressive BungalowCraftsman house lost its audience-clientele. As Wiebe notes, upon entering the war, Americans faced the ironic fact that they had borrowed freely from German and Austrian culture (Wiebe 264). Exemplifying just this sort of borrowing was the visual conception of the California Bungalow and the progressive house. But as the ranks of middleclass reformers thinned appreciably after the war, progressivism as a subculture slowly disappeared. The threat of labor violence and the taint of disloyalty had destroyed the credibility of the reform movement and many of its supporters (Wiebe 292). In the steady demise of the progressivist counterculture lay the ultimate decline and rejection of the California Bungalow as a respectable American house form. A "coherent loyalty" and "vital Americanism" were now being demanded. One had to be a member of the community in good standing, and convince one's fellow citizens accordingly. As a result, the appearance of being "different," once so jubilantly expressed with Tyrolean imagery, could now no longer be afforded; Germanic motifs on one's home became a potential social liability. House-plan books had to convince clients that California Bungalows were really "rock-ribbed American"13 or else drop the unsalable designs from their offerings. By the 1930s, the bungalow survived only in primarily Normanized, Anglicized and Mediterranean guises; the Bungalow-Craftsman house had in essence lost its "place," its cultural and rhetorical locus. One could say a socio-political Deluge had occurred, one that substantially swept Germanic associations from all that would be accepted as truly "American." Even though it may have been a genuinely American synthesis, the California Bungalow, with its Tyrolean chalet ancestry, could not withstand this diluvian surge of cultural purification.

\section{Notes}

'For example: Clay Lancaster, The American Bungalow: 1880-1930; Robert Winter, The California Bungalow; Anthony D. King, The Bungalow: the Production of a Global Culture.

2For example, see Thomas Gordon Smith, "John Hudson Thomas and the Progressive Spirit in Architecture, 1910-1920," Chapter 1; see also Judith V. May, "Struggle for Authority: A Comparison of Four Social Change Programs in Oakland, California," 21-66.

${ }^{3}$ Designs 197, 167, 661, and 195, 466, 676, 720.

'Henry Menken, Bungalowcraft, California Bungalow Homes, 4th edition. See Designs 67, 68-692, 205-623, 312 $712,671,672-695,687$.

${ }^{5}$ For example, see Designs 68-692, 205-623 and 672-695 in the 1913 Bungalowcraft catalog.

${ }^{6}$ Karen Current and William R. Current, Greene of Greene: Architects in the Residential Style. See text 12-13, 15, 16; photos and drawing 20-21, 24, 29, 30, 68 .

'Other Germanic-surname bungalow designers in California included Arthur Heineman and Alfred Heineman, Henry Menken of Bungalowcraft, and Eugene Otto Walter Murmann.

${ }^{8}$ For an account of anti-German activity in America during World War I, see Erik Kirschbaum, The Eradication of German Culture in the United States: 1917-1918; and Robert Henry Billigmeier, Americans from Germany: $A$ Study in Cultural Diversity, 134-149.

${ }^{9}$ For example, Senator Robert M. La Follette. See Carl H. Chrislock. "The German-American Role in Minnesota Politics, 1850-1950," A Heritage Deferred: The GermanAmericans in Minnesota, ed. Clarence A. Glasrud, 108-110.

${ }^{10}$ For example, Charles Matlack Price, The Practical Book of Architecture, 198-199, 207.

${ }^{11}$ Compare the quote from the DeLuxe Building Co. catalog above promoting "homes that are different."

${ }^{12}$ With regard to name changes, worth considering is the possibility that many architectural designs were retroactively dubbed "Mission" in order to obscure their Germanic overtones. The most famous example of a food changing names is, of course, the quintessentially "American" hot dog, before the War known as the "Frankfurter" or "Wiener" (Wien being the German spelling of Vienna).

${ }^{13}$ For example, see the Aladdin Company Catalog, "The Plaza," Nos. 29-32, 1917-1920. By 1929 the "Plaza," a double cross-gable California Bungalow, had been cut from Aladdin's catalog.

\section{Works Cited}

Aladdin Company Catalog. "The Plaza," Bay City, Michigan: Aladdin Co., Nos. 29-32, 1917-1920. 
Arnheim, Rudolf. The Dynamics of Architectural Form. Berkeley: University of California P, 1977.

Billigmeier, Robert Henry. Americans from Germany: A Study in Cultural Diversity. Belmont, CA: Wadsworth Publishing, 1974.

Brooks, H. Allen. The Prairie School. New York: W.W. Norton, 1976.

Chrislock, Carl H. "The German-American Role in Minnesota Politics, 1850-1950." A Heritage Deferred: The German-Americans in Minnesota. Clarence A. Glasrud, ed. Moorhead, Minnesota: Concordia College, 1981.

Clark, Robert Judson. "Louis Christian Mullgardt." Macmillan Encyclopedia of Architects, Vol. 3. New York: The Free P, 1982.

Current, Karen, and William R. Current. Greene of Greene: Architects in the Residential Style. Fort Worth, Texas: Ammon Carter Museum, 1974.

David, Arthur C. "An Architect of Bungalows in California." Architectural Record 20.4 (1905):306-315.

"The Development of the Modern Home," The Architect and Engineer of California, 38.2 (1914).

Goldman, Eric F. Rendez-Vous with Destiny. New York: Vintage Books, 1956.

Gowans, Alan. "Towards a Humane Environment: First Principles for Architectural Design and History." The Arts in a Democratic Society. Dennis Alan Mann, ed. Bowling Green, Ohio: Popular Press, 1977: 19-42.

Hawgood, John A. The Tragedy of German-America. New York: G.P. Putnam's Sons, 1940.

Hofstadter, Richard. The Age of Reform: From Bryan to F.D.R. New York: Vintage Books, 1955.

Kirschbaum, Erik. The Eradication of German Culture in the United States: 1917-1918. Stuttgart: HansDieter Heinz, 1986.

King, Anthony D. The Bungalow: the Production of a Global Culture. London: Routledge \& Kegan Paul, 1984.

Lancaster, Clay. The American Bungalow: 1880-1930. New York: Abbeville P, 1985.

Mackinson, Randell L. "Greene and Greene." In Esther McCoy, Five California Architects. New York: Praeger, 1975: 102-147.
May, Judith V. "Struggle for Authority: A Comparison of Four Social Change Programs in Oakland, California," Ph.D. dissertation, University of California, Berkeley, California, 1973.

Menken, Henry. Bungalowcraft, California Bungalow Homes. 4th ed. Los Angeles: The Bungalowcraft Co., 1913

Plan-Kraft. Los Angeles: De Luxe Building Co., ca. 1912.

Price, Charles Matlack. The Practical Book of Architecture. Philadelphia: J.B. Lippincott, 1916.

Rhoads, William B. "The Colonial Revival and the Americanization of Immigrants." The Colonial Revival in America. Alan Axelrod, ed. New York: W.W. Norton, 1985.

Saylor, Henry H. Bungalows. New York: McBride, Winston and Co., 1911.

Smith, Thomas Gordon. "John Hudson Thomas and the Progressive Spirit in Architecture, 1910-1920," Master of Architecture thesis, University of California, Berkeley, 1975.

"Some California Bungalows. Architectural Record. 18.3 (1905).

Stellman, Louis J. "The Swiss Chalet Type." Architectural Styles for Country Houses. Henry H. Saylor, ed. 1912. New York: Robert M. McBride, 1919.

Suzuki, Makoto. Wooden Houses. New York: Harry N. Abrams, 1979.

"Together for Oakland." Editorial. Oakland Enquirer, 1 January 1909.

Wiebe, Robert H. The Search for Order: 1877-1920. New York: Hill and Wang, 1967.

Wilson, Henry L. The Bungalow Book. Los Angeles: H.L. Wilson, 1908; Chicago: Wilson, 1910.

Winter, Robert. The California Bungalow. Los Angeles: Hennessey \& Ingalls, 1980.

"The Arroyo Culture." California Design 1910. T. Andersen, E. Moore, R. Winter, eds. Pasadena: California Design Publications, 1974.

Rodney Douglas Parker is an Assistant Professor of Architecture in the College of Architecture and Urban Planning at the University of Michigan, Ann Arbor, MI 48109. 